\title{
Surface Disinfestation of Resting Spores of Plasmodiophora brassicae Used to Infect Hairy Roots of Brassica spp.
}

\author{
T. Asano, K. Kageyama, and M. Hyakumachi
}

Laboratory of Plant Disease Science, Faculty of Agriculture, The United Graduate School of Agricultural Science, Gifu University, 1-1 Yanagido, Gifu 501-1193, Japan.

Accepted for publication 7 December 1998.

\begin{abstract}
Asano, T., Kageyama, K., and Hyakumachi, M. 1999. Surface disinfestation of resting spores of Plasmodiophora brassicae used to infect hairy roots of Brassica spp. Phytopathology 89:314-319.

Resting spores of Plasmodiophora brassicae were surface-disinfested by treatment with $2 \%$ chloramine-T for $20 \mathrm{~min}$ and then with an antibiotic solution $(1,000 \mathrm{ppm}$ of colistin sulfate, $1,000 \mathrm{ppm}$ of vancomycin hydrochloride, and 6,000 ppm of cefotaxime sodium) for 1 day. The disinfested resting spores were used to inoculate hairy roots of cabbage (Brassica oleracea var. capitata cv. Fuji Wase), Chinese cabbage (B. pekinensis cv. Musou Hakusai), turnip (B. rapa var. rapifera cv. Wase

susceptibility to clubroot in hairy roots were evident. Chinese cabbage and turnip hairy roots supported the highest percentages of root hair infection (53.3 to $80 \%$ ) and the greatest production of zoosporangial groups ( 8.5 to 32.5 per root). Moreover, gall formation was observed only on Chinese cabbage and turnip hairy roots. The morphology of zoosporangia, plasmodia, and resting spores in diseased hairy roots was found to be identical to that in infected intact plants by both light and scanning electron microscopy. Pathogenicity tests confirmed the infectivity of resting spores produced in hairy roots. Thus, the hairy root culture technique should prove useful as a dual culture system for $P$. brassicae.
\end{abstract} Okabu), and rape (B. napus line Dc 119). Differences among hosts in
Plasmodiophora brassicae Woronin, the causal agent of clubroot of crucifers, is a soilborne obligate pathogen. The fungus has never been axenically cultured, although axenic culture is a basic technique in physiological and etiological investigations of plant pathogens. Various investigations have been conducted on the use of dual cultures of $P$. brassicae with host tissue $(1,2,9,10,22,23)$, but the propagation efficiency of $P$. brassicae was low. In addition, it is very difficult to establish and maintain axenic dual cultures because galls are infested by many microorganisms and because the quantity of resting spores recovered from infected callus is less than that from intact clubroot (9). Recently, the use of hairy root cultures, induced by infection with Agrobacterium rhizogenes, has received considerable attention in the study of host-parasite relationships $(3,16,19)$. The culture of $P$. brassicae in association with hairy roots was first performed successfully by Mugnier (15) without any gall formation. Likewise, He (8) demonstrated the infection of hairy roots by $P$. brassicae using solid and liquid culture media. In a solid medium, root hair infection was observed but not gall formation; in a liquid medium, there was gall formation but not root hair infection. The galls formed in hairy roots were small, and the successful infection frequency was low (0 to 20\%). Graveland et al. (6) also found small galls but did not observe $P$. brassicae resting spores in the gall tissue of hairy roots. In short, a culture system comprising hairy roots and the pathogen has not been established.

Elimination of microorganisms associated with $P$. brassicae resting spores is necessary for in vitro dual culture. In previous reports $(6,8,15)$, resting spore suspensions were obtained from surface-sterilized galls, but such suspensions were not always disinfested. It was necessary to develop a rapid and effective technique for obtaining disinfested suspensions of resting spores as

Corresponding author : K. Kageyama; E-mail address: kageyama@cc.gifu-u.ac.jp

Publication no. P-1999-0208-02R

(C) 1999 The American Phytopathological Society inoculum for in vitro cultures. In this research, we developed a technique for the elimination of microorganisms from resting spore suspensions and for the establishment of an in vitro dual culture of P. brassicae and hairy roots of several Brassica spp.

\section{MATERIALS AND METHODS}

Preparation of the resting spore suspension from artificially infected clubroot. Inoculum for propagation of resting spores was prepared by the slurry method (24). The slurry consisted of $100 \mathrm{ml}$ of potting soil (Guransol, Sumitono Kagaku, Osaka, Japan) and $50 \mathrm{ml}$ of a resting spore suspension and had a final concentration of $1.0 \times 10^{7}$ spores per g. The slurry was mixed thoroughly and poured into a hole $3 \mathrm{~cm}$ in diameter and $2 \mathrm{~cm}$ deep in compost potting soil (Zeolite, Okutamakougyou Co. Ltd., Tokyo, Japan) contained in plastic pots $(11 \times 8 \mathrm{~cm})$. Seeds of turnip $(B$. rapa $\mathrm{L}$. var. rapifera Merz. cv. Wase Okabu) were surface-sterilized with $70 \%$ ethanol for $1 \mathrm{~min}$ and $10 \%$ hydrogen peroxide for $1 \mathrm{~h}$ and then rinsed three times in sterile distilled water. The surface-sterilized seeds were incubated for 1 day in the dark at $25^{\circ} \mathrm{C}$. The seedlings were planted in the slurry-amended potting soil and grown in the greenhouse at 20 to $25^{\circ} \mathrm{C}$. The galls were collected about 8 weeks after inoculation and washed thoroughly under running tap water to remove soil particles. The outer layers of the gall tissues were removed, and the central parts were surface-sterilized with $70 \%$ ethanol for $1 \mathrm{~min}$ and $10 \%$ sodium hypochlorite (available chlorine $0.5 \%$ ) for $20 \mathrm{~min}$. The galls were rinsed three times in sterile distilled water, cut into small pieces, macerated in a blender in $50 \mathrm{ml}$ of sterile distilled water for $3 \mathrm{~min}$, and then filtered through eight layers of cheesecloth. The filtrate was centrifuged at $1,700 \times g$ for $5 \mathrm{~min}$ and washed five times with sterile distilled water. The spore suspension was prepared with sterile distilled water and adjusted to a concentration of $5.0 \times 10^{7}$ spores per $\mathrm{ml}$.

Surface disinfestation of resting spores. The spore suspension was centrifuged at $1,700 \times g$ for $5 \mathrm{~min}$, and the supernatant was discarded. Resting spores were suspended in freshly prepared 
2\% chloramine-T solution (wt/vol) (Wako Pure Chemical Industries Ltd., Osaka, Japan) at room temperature for $20 \mathrm{~min}$ and then washed twice in sterile water by centrifugation as described. The resulting pellet was suspended in an antibiotic solution containing 1,000 ppm of colistin sulfate (Wako Pure Chemical Industries Ltd.), 1,000 ppm of vancomycin hydrochloride (Wako Pure Chemical Industries Ltd.), and 6,000 ppm of cefotaxime sodium (Hoechst Pharmaceuticals and Chemicals K. K., Tokyo) in distilled water and incubated at $25^{\circ} \mathrm{C}$ in the dark. After 1 day, the suspension was washed twice in sterile water by centrifugation. The resting spores were suspended in 1/10-strength modified Hoagland's solution (5 $\mathrm{mM} \mathrm{Ca}\left[\mathrm{NO}_{3}\right], 5 \mathrm{mM}$ $\mathrm{KNO}_{3}, 2 \mathrm{mM} \mathrm{MgSO}$, and $2 \mathrm{mM} \mathrm{KK_{2 }} \mathrm{PO}_{4} ; \mathrm{pH}$ 5.8) (12) with or without $100 \mathrm{ppm}$ of cefotaxime sodium. Resting spores not treated with chloramine- $T$ and antibiotics were used as the control treatment. The resting spore suspension was incubated in the dark at $25^{\circ} \mathrm{C}$. After 10 days, drops (about $10 \mu \mathrm{l}$ ) of the spore suspension were placed on glass slides, and germinated and ungerminated resting spores were directly counted by using a Nomarski differential interference contrast optic microscope (Olympus Optical Co. Ltd., Tokyo). At least 300 spores were randomly counted per slide.

Assessment of contamination of resting spores. To determine whether or not the spore suspension was disinfested, the growth of microbial contaminants was assessed twice, first at the time that chemicals were removed from the spores and again when spore germination was assessed. To assess contamination, five droplets of the suspension were placed on plate count agar medium (Nissui Chemical Co. Ltd., Tokyo) in 9-cm petri plates and incubated at $25^{\circ} \mathrm{C}$ in the dark. After 1 week, the plates were visually assessed for colony formation in the droplets. This experiment was conducted three times with three replicates per experiment.

Hairy root strains. Seven hairy root strains were induced in plants from four crucifer species: cabbage, B. oleracea $\mathrm{L}$. var. capitata L. cv. Fuji Wase; Chinese cabbage, B. pekinensis (Lour.) Rupr. (formerly B. rapa var. pekinensis) cv. Musou Hakusai; turnip cultivar Wase Okabu (Takii Seed Co., Ltd., Kyoto); and rape, B. napus L. line Dc 119 (Tohoku Seed Co., Ltd., Tochigi, Japan) (Table 1). All cultivars were highly susceptible to $P$. brassicae. Hairy roots were subcultured every 4 weeks on petri dishes containing Murashige and Skoog's (MS) agar medium (17).

Inoculation with $\boldsymbol{P}$. brassicae. Hairy roots of Brassica spp. were inoculated with resting spores of $P$. brassicae by the method of Graveland et al. (6) with modifications. Hairy roots were cut into segments approximately $3 \mathrm{~cm}$ long, placed on MS medium in 9-cm petri dishes, and cultured in the dark at $25^{\circ} \mathrm{C}$ for 5 days to allow growth of root hairs. Five milliliters of disinfested resting spore suspension $\left(5.0 \times 10^{6}\right.$ spores per $\mathrm{ml}$ in $1 / 10$-strength Hoagland's solution supplemented with $100 \mathrm{ppm}$ of cefotaxime sodium) was put over the hairy roots, and the plates were incubated in the dark at $25^{\circ} \mathrm{C}$. After 12 days, the inoculated hairy roots were observed for root hair infection in the taproot $(0$ to $7 \mathrm{~cm}$ from the basal part of the hairy root) by using an inverted microscope (Olympus Optical Co. Ltd.). The hairy roots were incubated for 7 weeks under the same conditions. The gall formation was assessed on the basis of the number of galls and fresh weight of galls per plate.

TABLE 1 . Hairy root strains used in this study

\begin{tabular}{lll}
\hline Hairy root strain & \multicolumn{1}{c}{ Host plant } & Bacterial strain $^{\mathrm{z}}$ \\
\hline BO. 123 & Cabbage & ArM-123 \\
BP. 123 & Chinese cabbage & ArM-123 \\
BP. 1724 & Chinese cabbage & NIAES 1724 \\
BR. 13 & Turnip & A13 \\
BR. 123 & Turnip & ArM-123 \\
BN. 123 & Rape & ArM-123 \\
BN. 1725 & Rape & NIAES 1725 \\
\hline
\end{tabular}

${ }^{\mathrm{z}}$ ArM-123, NIAES 1724 and A13, and NIAES 1725 were obtained from Shizuoka Prefectural Agricultural Experiment Station; Research Institute of Agricultural Research, Ishikawa Agricultural College; and Lion Corporation Research Institute, respectively.
The control treatment consisted of hairy roots inoculated with $5 \mathrm{ml}$ of 1/10-strength Hoagland's solution amended with $100 \mathrm{ppm}$ of cefotaxime sodium.

Intact seedlings of Brassica cultivars, in which the transformed roots had been induced, were also inoculated with resting spores. The inoculum slurry consisted of $100 \mathrm{ml}$ of autoclaved soil and $50 \mathrm{ml}$ of spore suspension in distilled water comprising $5.0 \times 10^{6}$ disinfested resting spores per gram of slurry. This slurry was mixed thoroughly and poured into a hole $(3 \mathrm{~cm}$ in diameter and $2 \mathrm{~cm}$ deep) in the compost contained in a plastic pot $(6 \times 7.5 \mathrm{~cm})$. Five 1-dayold seedlings were then transplanted to the slurry-amended compost. After a 12-day incubation period, the seedlings were washed thoroughly under running tap water to remove soil particles, and the taproots were stained with $0.005 \%$ cotton blue solution in $50 \%$ acetic acid for more than a day. Zoosporangial clusters were counted on $4 \mathrm{~cm}$ of each taproot from the basal part of the hypocotyl.

Eight weeks after incubation, the plants were examined for clubroot symptoms. For each plant, the disease index class was visually determined by using a scale of 0 to 3 , in which $0=$ no swelling visible; 1 = slight swelling, usually confined to lateral roots; 2 = moderate swelling on lateral or taproots, and $3=$ severe swelling on lateral or taproots. The number of plants in class 0 was multiplied by 0 , in class 1 by 20 , in class 2 by 80 , and in class 3 by 100 , and sum was divided by the total number of plants to give a disease severity for each treatment (18). Fresh weights of roots with galls were also recorded. Five seedlings were planted in each pot. Two pots were used for root hair infection and zoosporangial enumeration, and three pots were used for assessment of gall formation and disease severity. The experiment was conducted twice.

Histology of $\boldsymbol{P}$. brassicae in hairy roots. To observe root hair infection, the hairy roots were washed under tap water, stained as described above, and then examined with a light microscope. For observation of secondary plasmodia and resting spores, the sections of gall tissues were stained with $0.05 \%$ cotton blue solution in $50 \%$ acetic acid, and specimens were examined by light microscopy.

For scanning electron microscopy, galls derived from hairy roots were cut into approximately $3-\mathrm{mm}$ pieces. The tissues were fixed in $5 \%$ glutaraldehyde in a $0.1 \mathrm{M}$ phosphate buffer $(\mathrm{pH} \mathrm{7.2)}$ at room temperature for $4 \mathrm{~h}$ and washed four or five times with fresh buffer. The fixed tissues were postfixed with $1 \%$ osmic acid in the same buffer at room temperature for $2 \mathrm{~h}$ and then rinsed four or

TABLE 2. Effects of several chemicals on the suppression of microorganisms and germination of resting spores of Plasmodiophora brassicae

\begin{tabular}{|c|c|c|c|c|}
\hline \multirow[b]{2}{*}{ Treatment $^{\mathrm{u}}$} & \multirow{2}{*}{$\begin{array}{c}\text { Cefotaxime } \\
\text { sodium }^{\mathrm{V}}\end{array}$} & \multicolumn{2}{|c|}{ Contamination $^{\mathrm{w}}(\%)$} & \multirow{2}{*}{$\begin{array}{c}\text { Germination } \\
(\%)\end{array}$} \\
\hline & & 0 days & 10 days & \\
\hline \multirow[t]{2}{*}{ Control } & - & $100.0 \mathrm{~b}^{\mathrm{y}}$ & $100.0 \mathrm{~b}$ & $15.8 \mathrm{abc}$ \\
\hline & + & $71.1 \mathrm{~b}$ & $100.0 \mathrm{~b}$ & $16.0 \mathrm{abc}$ \\
\hline \multirow[t]{2}{*}{ Chloramine- $\mathrm{T}$} & - & $0.0 \mathrm{a}$ & $68.9 \mathrm{~b}$ & $8.1 \mathrm{a}$ \\
\hline & + & $0.0 \mathrm{a}$ & $68.9 \mathrm{~b}$ & $15.8 \mathrm{abc}$ \\
\hline \multirow[t]{2}{*}{ Antibiotics $^{\mathrm{Z}}$} & - & $6.7 \mathrm{a}$ & $0.0 \mathrm{a}$ & $19.4 \mathrm{bc}$ \\
\hline & + & $11.1 \mathrm{a}$ & $0.0 \mathrm{a}$ & $27.0 \mathrm{c}$ \\
\hline Chloramin-T & - & $0.0 \mathrm{a}$ & $0.0 \mathrm{a}$ & $9.8 \mathrm{ab}$ \\
\hline+ antibiotics & + & $0.0 \mathrm{a}$ & $0.0 \mathrm{a}$ & $15.1 \mathrm{abc}$ \\
\hline
\end{tabular}

u Resting spores were suspended in $2 \%$ chloramine-T for $20 \mathrm{~min}$, antibiotic solution for 1 day, or a combination of the two.

$\checkmark$ After treatment with chloramine-T and antibiotics, resting spores were suspended in 1/10-strength Hoagland's solution with (+) or without (-) $100 \mathrm{ppm}$ of cefotaxime sodium.

" Percentage of contamination was assessed at the time of treatment with chemicals and 10 days after treatment. Data are the means of three trials, each with three petri plates.

${ }^{x}$ Germination of resting spores was assessed with a Nomarski interference optic microscope. Values are means of three replicates of samples with more than 300 spores per sample of spore suspension.

y Means within a column followed by the same letter are not significantly different $(P<0.05)$ according to Duncan's multiple range test.

${ }^{\mathrm{z}}$ Colistin sulfate $(1,000 \mathrm{ppm})$, vancomycin hydrochloride $(1,000 \mathrm{ppm})$, and cefotaxime sodium $(6,000 \mathrm{ppm})$. 

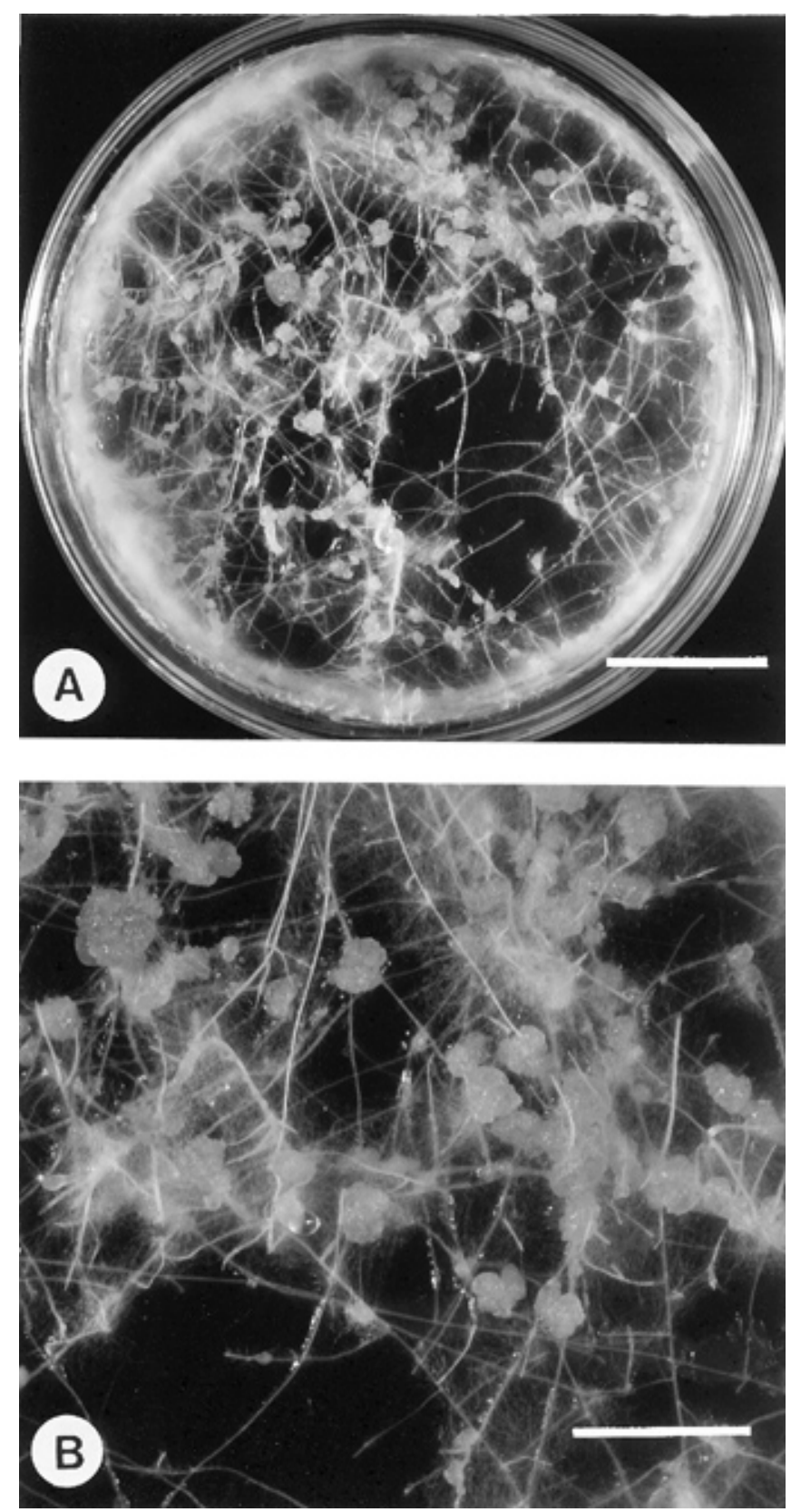

Fig. 1. Gall formation on turnip hairy roots 8 weeks after inoculation with resting spores of Plasmodiophora brassicae. A, In vitro mass propagation of galls on Murashige and Skoog's medium. Bar $=20 \mathrm{~mm}$. B, Galls shown at high magnification. Bar $=10 \mathrm{~mm}$. five times with the buffer to remove excess osmic acid. The doublefixed samples were dehydrated through an ethanol series of 25 , $50,70,90,95,100$, and $100 \%$ for 15 min each. The ethanol was removed by changes of ethanol and amyl acetate at 1:3, 1:1, and $3: 1$ and two changes of $100 \%$ amyl acetate for 25 min each. The specimens were critical-point dried, mounted on specimen studs, and sputter coated with gold palladium. Samples were examined with a scanning electron microscope (model JSM-U3; Japan Electron Optics, Tokyo) operated at $10 \mathrm{kV}$.

Pathogenicity of resting spores derived from galls in hairy roots. Resting spores from galls developed in hairy root cultures after 8 weeks of incubation on MS medium were used to inoculate susceptible turnip seedlings ('Wase Okabu') by the slurry method described above. The slurry consisted of $100 \mathrm{ml}$ of autoclaved soil and $50 \mathrm{ml}$ of the spore suspension in distilled water at a concentration of $1.0 \times 10^{6}$ disinfested resting spores per gram of slurry. This slurry was mixed thoroughly and poured into a hole $(3 \mathrm{~cm}$ in diameter and $2 \mathrm{~cm}$ deep) in the compost contained in a plastic pot $(11 \times 8 \mathrm{~cm})$. One-day-old turnip seedlings were then transplanted to the slurryamended compost and grown in the greenhouse. Seedlings grown in compost soil amended with slurry lacking resting spores were used as the uninoculated control treatment. After 8 weeks, the seedlings were assessed for clubroot symptoms. The experiment was conducted twice with five replicates per experiment.

Statistical analysis. Each experiment had a completely randomized design with two, three, or five replicates per treatment. Percentage data were transformed by square root or arcsine transformations to stabilize the variance (4). The treatment means were separated by Duncan's multiple range test $(P<0.05)$.

\section{RESULTS}

Surface disinfestation of resting spores. Resting spores treated with chloramine-T showed no contamination at the time of the treatment, but a high percentage of contamination was found 10 days after treatment (Table 2). Exposing the spores to antibiotics did not eliminate any bacteria at the time of treatment. The combination of chloramine-T and antibiotics completely eliminated contamination even 10 days after treatment, and the treated spores were as germinable as those of the untreated controls. To prevent reinfection of resting spores during incubation, cefotaxime sodium was added to the spore suspension. The addition did not affect the effectiveness of disinfestation or the germinability of resting spores.

Infection of hairy roots. Root hair infection was observed in all seven strains of hairy roots, but the frequencies differed among the host plant species (Table 3). Chinese cabbage and turnip hairy roots showed up to $80.0 \%$ incidence of root hair infection. In contrast, the percentages of root hair infection in cabbage and rape hairy roots were moderate and low, respectively. Similar trends were observed with the number of zoosporangial groups. Chinese cabbage and turnip hairy roots developed galls 8 weeks after

TABLE 3. Root hair infection and gall formation in hairy roots inoculated with Plasmodiophora brassicae ${ }^{\mathrm{x}}$

\begin{tabular}{|c|c|c|c|c|c|}
\hline \multirow[b]{2}{*}{ Hairy root strain ${ }^{y}$} & \multicolumn{2}{|c|}{ Root hair infection } & \multicolumn{3}{|c|}{ Gall formation } \\
\hline & $\begin{array}{l}\text { Infection } \\
(\%)\end{array}$ & $\begin{array}{l}\text { Zoosporangial groups/ } \\
\text { infected hairy root (no.) }\end{array}$ & $\begin{array}{l}\text { Infection } \\
(\%)\end{array}$ & $\begin{array}{l}\text { Galls/infected } \\
\text { hairy root (no.) }\end{array}$ & $\begin{array}{l}\text { Gall fresh weight/ } \\
\text { infected hairy root }(\mathrm{mg})\end{array}$ \\
\hline BO. 123 & $6.7 \mathrm{a}^{\mathrm{z}}$ & $0.3 \mathrm{a}$ & $0.0 \mathrm{a}$ & $0.0 \mathrm{a}$ & $0.0 \mathrm{a}$ \\
\hline BP. 123 & $73.3 \mathrm{~b}$ & $18.5 \mathrm{ab}$ & $33.3 \mathrm{ab}$ & $39.9 \mathrm{a}$ & $14.8 \mathrm{a}$ \\
\hline BP. 1724 & $80.0 \mathrm{~b}$ & $22.0 \mathrm{ab}$ & $13.3 \mathrm{ab}$ & $18.3 \mathrm{a}$ & $3.8 \mathrm{a}$ \\
\hline BR. 123 & $53.3 \mathrm{ab}$ & $8.5 \mathrm{a}$ & $46.7 \mathrm{~b}$ & $276.6 \mathrm{~b}$ & $312.3 \mathrm{~b}$ \\
\hline BR. 13 & $80.0 \mathrm{~b}$ & $32.5 \mathrm{~b}$ & $20.0 \mathrm{ab}$ & $75.2 \mathrm{a}$ & $164.3 \mathrm{ab}$ \\
\hline BN. 123 & $26.7 \mathrm{ab}$ & $1.9 \mathrm{a}$ & $0.0 \mathrm{a}$ & $0.0 \mathrm{a}$ & $0.0 \mathrm{a}$ \\
\hline BN. 1725 & $46.7 \mathrm{ab}$ & $4.1 \mathrm{a}$ & $0.0 \mathrm{a}$ & $0.0 \mathrm{a}$ & $0.0 \mathrm{a}$ \\
\hline
\end{tabular}

$\mathrm{x}$ Values are means of three trials, each with five replicates. Resting spores were obtained from the galls 8 weeks after inoculation.

y BO., BP., BR., and BN. = cabbage, Chinese cabbage, turnip, and rape, respectively.

${ }^{\mathrm{z}}$ Means within a column followed by the same letter are not significantly different $(P<0.05)$ according to Duncan's multiple range test. 
inoculation, while cabbage and rape hairy roots showed no gall formation (Table 3). The number and fresh weight of galls formed in turnip hairy roots were both greater than those of Chinese cabbage hairy roots. The galls in turnip hairy roots were spherical or spindle shaped and were scattered throughout the hairy roots (Fig. 1). Root hair infection and gall formation were not observed in uninoculated controls.

Microscopic observations. There were no differences in the structure of zoosporangia among the seven hairy root strains. All stages in root hair infection were observed, including the development of immature zoosporangia and complete evacuation of zoosporangia (Fig. 2). The morphology of zoosporangia and the growth stages of root hair infection in hairy root cultures were identical to the morphology and growth stages in infected intact plants.

The secondary plasmodia and immature resting spores within whitish gall tissues were observed by light and electron microscopy 6 weeks after inoculation. Eight weeks after inoculation, however, galls became brownish, and a number of mature resting spores were observed in the gall tissues (Fig. 3). The cortical in- fection phase of the pathogen was also identical in hairy roots and diseased plants grown in infested soil.

Pathogenicity of resting spores from diseased hairy roots. The pathogenicity of resting spores from 8-week-old galls in hairy roots was tested on turnip seedlings by the slurry method (Table 4). Resting spores from galls developed in hairy root cultures showed the same infectivity as those from infected intact plants. All inoculated plants had shown severe clubroot symptoms.

Susceptibility of the intact plant. Root hair infection was observed in all host species (Table 5). The percentage of infected plants and the number of zoosporangial groups per root were not significantly different among host plants. All four plant species also formed galls with high disease severity.

\section{DISCUSSION}

There have been several studies of dual cultures of obligate parasites $(5,7,21)$. However, dual-culture techniques are not common. Obtaining surface-disinfested spores from infected plants has been
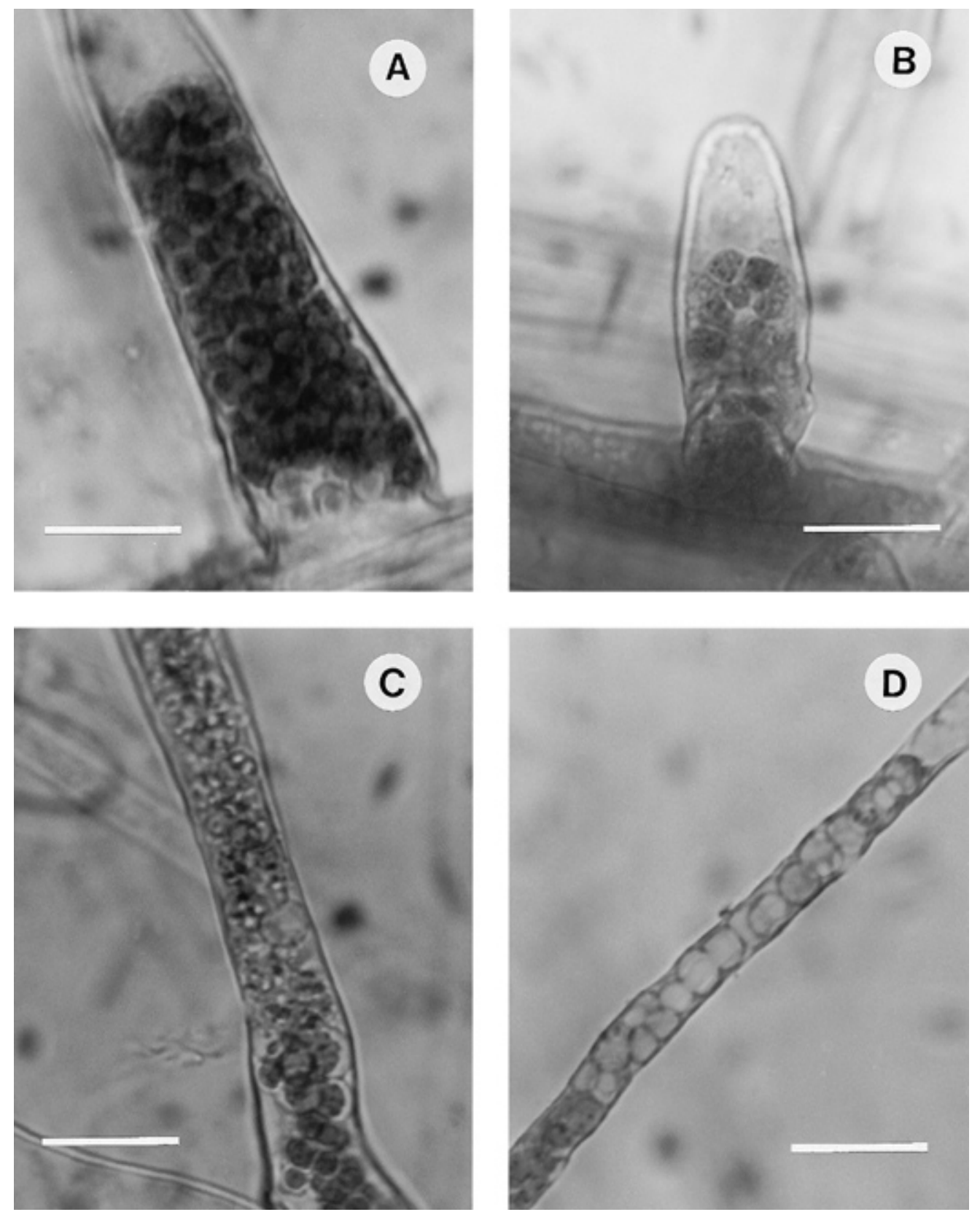

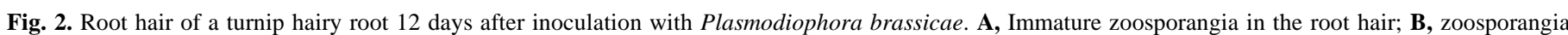

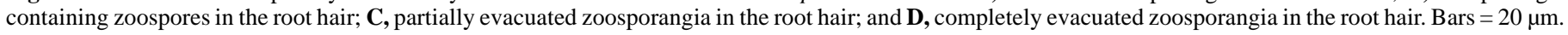


a major technical problem. Sacristan and Hoffmann (20), Mugnier (15), and He (8) obtained disinfested resting spore suspensions of $P$. brassicae by surface sterilization of whitish clubroot galls. In preliminary experiments for this study, however, the previously reported methods were not effective in the elimination of microorganisms. Mertz et al. (13) and Mosse (14) obtained axenic spores in arbuscular mycorrhizal fungi with direct treatment using a disinfectant solution. In the current study, disinfectants were directly

TABLE 4. Pathogenicity of resting spores of Plasmodiophora brassicae to turnip seedlings

\begin{tabular}{lccc}
\hline \multirow{2}{*}{$\begin{array}{l}\text { Resting spore } \\
\text { source }\end{array}$} & \multirow{2}{*}{$\begin{array}{c}\text { Viability of resting } \\
\text { spores }^{\mathrm{x}}(\%)\end{array}$} & \multicolumn{2}{c}{ Clubroot } \\
\cline { 3 - 4 } & $79.3 \mathrm{a}^{\mathrm{z}}$ & $100.0 \mathrm{~b}$ & $100.0 \mathrm{~b}$ \\
Hairy root & $77.5 \mathrm{a}$ & $100.0 \mathrm{~b}$ & $100.0 \mathrm{~b}$ \\
Intact plant & $\ldots$ & $0.0 \mathrm{a}$ & $0.0 \mathrm{a}$ \\
Control & $\ldots$ & Didence $(\%)$ & Disease severity \\
\hline
\end{tabular}

${ }^{\mathrm{w}}$ Resting spores were obtained from the galls formed on hairy roots or diseased intact plants 8 weeks after inoculation.

${ }^{x}$ Viability of resting spores was assessed by Nomarski interference optic microscopy.

${ }^{\mathrm{y}}$ Disease severity $=[(N 0 \times 0)+(N 1 \times 20)+(N 2 \times 80)+(N 3 \times 100)] /(N 0+$ $N 1+N 2+N 3)$. N0, N1, N2, and $N 3$ are the numbers of seedlings in disease index classes 0 to 3 , respectively. Disease index classes: $0=$ no clubroot; 1 = slight swelling; 2 = moderate swelling on lateral or taproots; and $3=$ severe swelling on lateral or taproots.

${ }^{\mathrm{z}}$ Means within a column followed by the same letter are not significantly different $(P<0.05)$ according to Duncan's multiple range test.
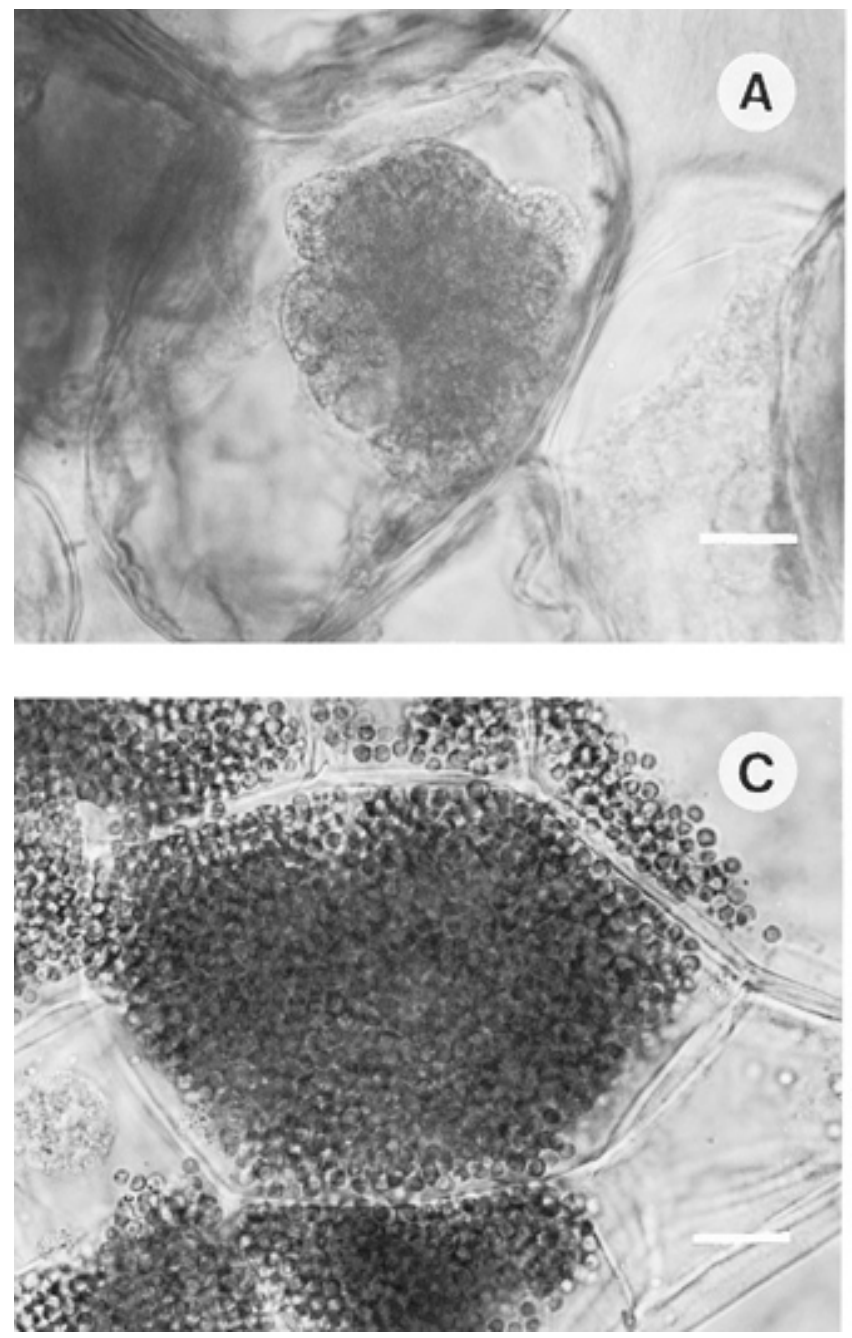

applied to the resting spores for elimination of microorganisms. Incubation of $P$. brassicae resting spores in 2\% chloramine-T for $20 \mathrm{~min}$ and then in antibiotics for 1 day prevented the multiplication of microbes without affecting germination.

We were successful in establishing root hair infection and gall formation in hairy root cultures. Compared with the results of $\mathrm{He}$ (8) and Graveland et al. (6), the percentages of gall formation and the number of galls were much higher in the current study. Two

TABLE 5. Root hair infection and gall formation on several Brassica plants $^{\mathrm{x}}$

\begin{tabular}{lcccccc}
\hline & \multicolumn{2}{c}{ Root hair infection } & & \multicolumn{3}{c}{ Gall formation } \\
\cline { 2 - 3 } \cline { 5 - 7 } Host plant & $\begin{array}{c}\text { Incidence } \\
(\%)\end{array}$ & $\begin{array}{c}\text { Zoosporangial } \\
\text { groups (no.) }\end{array}$ & $\begin{array}{c}\text { Incidence } \\
(\%)\end{array}$ & $\begin{array}{c}\text { Disease } \\
\text { severity }\end{array}$ & $\begin{array}{c}\text { Fresh } \\
\text { wt }(\mathrm{g})\end{array}$ \\
\hline Cabbage & $100.0 \mathrm{a}^{\mathrm{z}}$ & $\begin{array}{r}100.2 \mathrm{a} \\
\end{array}$ & & $100.0 \mathrm{a}$ & $100.0 \mathrm{a}$ & $0.9 \mathrm{a}$ \\
Chinese cabbage & $100.0 \mathrm{a}$ & $53.8 \mathrm{a}$ & & $100.0 \mathrm{a}$ & $100.0 \mathrm{a}$ & $1.4 \mathrm{~b}$ \\
Turnip & $100.0 \mathrm{a}$ & $86.6 \mathrm{a}$ & & $100.0 \mathrm{a}$ & $100.0 \mathrm{a}$ & $2.2 \mathrm{c}$ \\
Rape & $100.0 \mathrm{a}$ & $81.2 \mathrm{a}$ & & $100.0 \mathrm{a}$ & $100.0 \mathrm{a}$ & $1.8 \mathrm{bc}$ \\
\hline
\end{tabular}

$x$ Values are means of two trials. Two replicates were used for the root hair infection experiment, and three replicates were used for the gall formation experiment.

Disease severity $=[(N 0 \times 0)+(N 1 \times 20)+(N 2 \times 80)+(N 3 \times 100)] /(N 0+$ $N 1+N 2+N 3) . N 0, N 1, N 2$, and $N 3$ are the numbers of seedlings in disease index classes 0 to 3 , respectively. Disease index classes: $0=$ no clubroot; 1 = slight swelling; $2=$ moderate swelling on lateral and/or taproots; and $3=$ severe swelling on lateral and/or taproots.

${ }^{\mathrm{z}}$ Means within a column followed by the same letter are not significantly different $(P<0.05)$ according to Duncan's multiple range test.
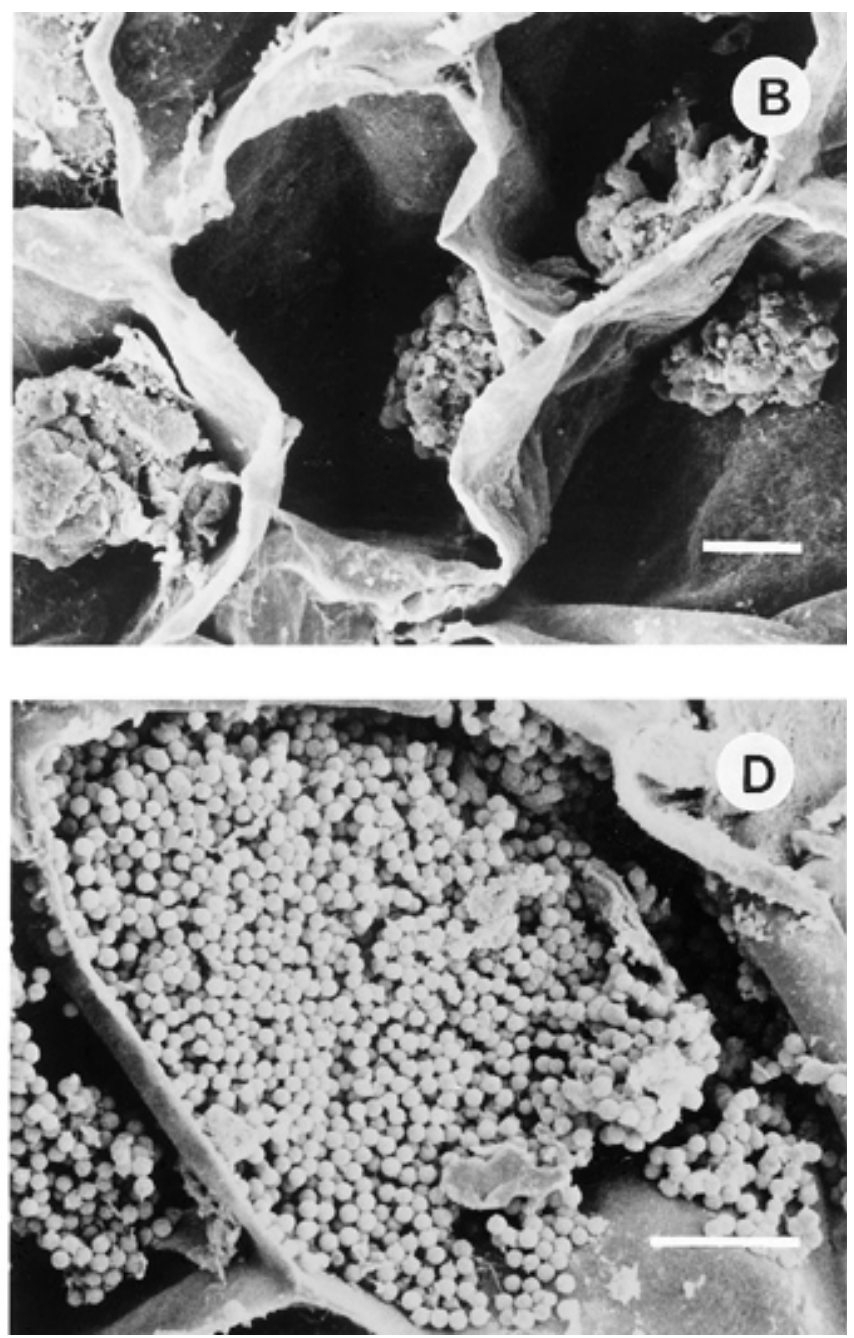

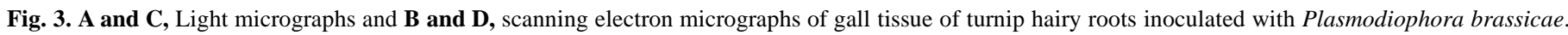


the gall tissue. Bars $=20 \mu \mathrm{m}$. 
factors contributed to the differences. First, using a disinfested resting spore suspension allowed an effective use of more resting spores $\left(5 \times 10^{6}\right.$ spores in $\left.5 \mathrm{ml}\right)$ for inoculation. The use of more resting spores may have increased the chance of infection, resulting in root hair infection and gall formation in lateral roots as well as taproots (data not shown). A second factor was the use of different host plant species. In the current study, susceptibility of hairy roots differed among plant species. Higher percentages of root hair infections were obtained in Chinese cabbage (B. pekinensis) and turnip (B. rapa) hairy roots. Furthermore, no gall formation was observed in cabbage and rape hairy roots belonging to $B$. olerace a and $B$. napus, respectively. B. pekinensis and $B$. rapa were not used in previous studies $(6,8,15)$. In those experiments, the hairy roots were induced in B. oleracea and B. napus.

Although all plant species used in our work were highly susceptible to $P$. brassicae, there were differences in susceptibility among the strains of hairy roots, probably resulting from differing culture conditions between inoculations of intact host plants and hairy roots. In inoculations of hairy roots, environmental factors, culture media, or moisture conditions were not optimal for the development of clubroot disease. In fact, Chinese cabbage and turnip hairy roots grew vigorously and rapidly under the conditions of our research, but cabbage and rape hairy roots grew more slowly. Therefore, galls formed in Chinese cabbage and turnip hairy roots but not in cabbage and rape hairy roots. Another possibility is that the physiological characteristics of hairy roots might not always be identical to those of intact roots and that the responses of hairy roots to the clubroot pathogen might be different from those of intact roots. Isa et al. (11) reported that water-soluble mucilages produced by hairy roots of Astragalus gummifer were not the same as those of the mother plant.

Turnip hairy roots will be more useful for dual cultures of $P$. brassicae than those of Chinese cabbage, because they formed large and numerous galls. This difference in gall formation between turnip and Chinese cabbage hairy roots is probably a reflection of the intact plant's properties. In short, the clubbed roots of intact turnip were enlarged, whereas those of intact Chinese cabbage were slender. Furthermore, symptoms exhibited by the diseased roots of turnip were more severe than those of Chinese cabbage.

The hairy root culture technique for $P$. brassicae has obvious advantages over callus culture systems because it permits observation of fungal development in vitro. The spores formed in hairy root cultures are viable and can infect intact host plants. In contrast, callus cultures support poor growth of P. brassicae (9), and resting spores are not easily obtained. However, continuous cultures have not yet been achieved by the hairy root culture technique. Continuous cultures on agar medium are a common technique for maintaining and propagating facultative parasites and saprophytes. Thus, it would be highly desirable to develop a continuous subculture technique in association with hairy roots in vitro.

\section{ACKNOWLEDGMENTS}

We thank M. Otani, H. Kakutani, and K. Ohta for the bacterial strains and B. Duffy and S. N. Mondal for correcting the English in the manuscript.

\section{LITERATURE CITED}

1. Buczacki, S. T. 1980. Culture of Plasmodiophora brassicae in host callus tissue. Pages 145-150 in: Tissue Culture Methods for Plant Pathol- gists. D. S. Ingram and J. P. Helgeson, eds. Blackwell Scientific, Oxford.

2. Dekhuijzen, H. M. 1975. The enzymatic isolation of secondary vegetative plasmodia of Plasmodiophora brassicae from callus tissue of Brassica campestris. Physiol. Plant Pathol. 6:187-192.

3. Díaz, C. L., Spaink, H. P., Wijffelman, C. A., and Kijne, J. W. 1995. Genomic requirements of Rhizobium for nodulation of white clover hairy roots transformed with the pea lectin gene. Mol. Plant-Microbe Interact. 8:348-356.

4. Gomez, K. A., and Gomez, A. A. 1984. Statistical Procedures for Agricultural Research. 2nd ed. J. Wiley \& Sons, New York.

5. Goyal, B. K., Verma, P. R., Seguin-Swartz, G., and Spurr, D. T. 1996. Growth of Albugo candida in leaf callus cultures of Brassica rapa. Can. J. Plant Pathol. 18:225-232.

6. Graveland, R., Dale, P., and Mithen, R. 1992. Gall development in hairy root cultures infected with Plasmodiophora brassicae. Mycol. Res. 96: 225-228.

7. Hampson, M. C., Coomber, J. W., and Debnath, S. C. 1997. Dual culture of Solanum tuberosum and Synchytrium endobioticum (pathotype 2). Myclogia 89:772-776.

8. He, Y.-K. 1991. Infection of Ri T-DNA-transformation roots by Plasmodiophora brassicae in Brassica crops. Sci. China (Ser. B) 34: 1444-1451.

9. Ikegami, H. 1992. Studies on the clubroot of cruciferous plants. X. Proliferation and pathogenicity of Plasmodiophora brassicae in infected callus tissue. Proc. Kansai Plant Prot. 34:17-28.

10. Ingram, D. S. 1969. Growth of Plasmodiophora brassicae in host callus. J. Gen. Microbiol. 55:9-18.

11. Isa, T., Ogasawara, T., and Kaneko. H. 1989. Induction of hairy-root from Astragalus plant, and musilage production by the hairy root. Plant Tiss. Cult. Lett. 6:134-137.

12. MacFarlane, I. 1970. Germination of resting spores of Plasmodiophora brassicae. Trans. Br. Mycol. Soc. 55:97-112.

13. Mertz, S. M., Heithaus, J. J., and Bush, R. L. 1979. Mass propagation of axenic spores of the endomycorrhizal fungus Gigaspora margarita. Trans. Br. Mycol. Soc. 72:167-169.

14. Mosse, B. 1962. The establishment of vesicular-arbuscular mycorrhiza under aseptic conditions. J. Gen. Microbiol. 27:509-520.

15. Mugnier, J. 1987. Infection by Polymyxa beate and Plasmodiophora brassicae of roots containing root-inducing transferred DNA of Agrobacterium rhizogenes. Phytopathology 77:539-542.

16. Mugnier, J., and Mosse, B. 1987. Vesicular-arbuscular mycorrhizal infection in transformed root-inducing T-DNA roots grown axenically. Phytopathology 77:1045-1050.

17. Murashige, T., and Skoog, F. 1962. A revised medium for rapid growth and bioassays with tobacco tissue cultures. Physiol. Plant. 15:437497.

18. Naiki, T., Kageyama, K., and Ikegami, H. 1978. Studies on the clubroot of cruciferous plants. II. The relation of spore density of Plasmodiophora brassicae Wor. to the root hair infection and club formation in Chinese cabbage. Ann. Phytopathol. Soc. Jpn. 44:432-439.

19. Plenchette, C., Declerck, S., Diop, T. A., and Strullu, D. G. 1996. Infectivity of monoaxenic subcultures of the arbuscular mycorrhizal fungus Glomus versiforme associated with Ri-T-DNA-transformed carrot root. Appl. Microbiol. Biotechnol. 46:545-548.

20. Sacristan, M. D., and Hoffmann, F. 1979. Direct infection of embryogenic tissue cultures of haploid Brassica napus with resting spores of Plasmodiophora brassicae. Theor. Appl. Genet. 54:129-132.

21. Sinha, O. K. 1995. Dual culture: Fungi. Pages 289-300 in: Molecular Methods in Plant Pathology. R. H. Singh and U. S. Singh, eds. CRC Press, Boca Raton, FL.

22. Strandberg, J. O., Williams, P. H., and Yukawa, Y. 1966. Monoxenic culture of Plasmodiophora brassicae with cabbage tissue. (Abstr.) Phytopathology 56:903.

23. Tommerup, I. C., and Ingram, D. S. 1971. The life-cycle of Plasmodiophora brassicae Woron. in Brassica tissue cultures and in intact roots. New Phytol. 70:327-332.

24. Toxopeus, H., and Janssen, A. M. P. 1975. Clubroot resistance in turnip. II. The slurry screening method and clubroot races in the Netherlands. Euphytica 24:751-755. 